ROCZNIKI NAUK SPOEECZNYCH

Tom 13(49), numer $1-2021$

DOI: https://doi.org/10.18290/rns21491.6

TERESA SASIŃSKA-KLAS

\title{
WYZWANIA KOMUNIKACYJNE W CZASACH PŁYNNEJ PANDEMII - PERSPEKTYWA SOCJOLOGICZNA
}

Analiza tematu zawartego w tytule artykułu, dedykowanego wieloletniemu, wysoce cenionemu przyjacielowi - teologowi, medioznawcy, ks. prof. dr hab. Leonowi Dyczewskiemu, zostanie rozpoczęta od dość obszernego, a zarazem skłaniającego do głębokiego przemyślenia cytatu pochodzącego z książki kanadyjskiego medioznawczy, Marshalla McLuhana, Zrozumieć media. Przedtużenia człowieka (tytuł $\mathrm{w}$ oryginale: Understanding media. The extensions of man, New York, Signet Books, 1964). Zaprezentowany cytat stanowi myśl przewodnią podjętej analizy i dotyczyć będzie następujących kwestii:

Wprowadzenie nowych środków przekazu i rodzajów techniki, za pomocą których wzmacniamy i przedłużamy siebie samych, stanowi potężną zbiorową operację chirurgiczną przeprowadzaną na ciele społeczeństwa $\mathrm{z}$ całkowitym pominięciem środków bakteriobójczych. Jeśli konieczna jest operacja, należy brać pod uwagę prawdopodobieństwo zainfekowania całego systemu podczas zabiegu. Jeśli chodzi o operowanie społeczeństwa za pomocą nowej techniki, to nie nacięte miejsca są najbardziej narażone na infekcję. Obszar wywierania wpływu i nacięcia jest porażony. To cały system podlega zmianom. Wrażenia odniesione pod wpływem radia są słuchowe. Wrażenia odniesione pod wpływem fotografii są wzrokowe. Każdy nowy bodziec prowadzi do zaburzenia równowagi między zmysłami. To, czego obecnie poszukujemy, to albo sposób kontrolowania tych zmian w proporcjach między zmysłami psychicznego i społecznego systemu, albo sposób na całkowite ich uniknięcie. Fakt, że nosisz w sobie chorobę, która nie daje żadnych objawów, świadczy o Twojej odporności. Żadne społeczeństwo nie ma na tyle wystarczającej wiedzy na temat swoich działań, żeby wykształcić

Prof. dr hab. TERESA SASIŃSKA-KLAS - Zakład Dziennikarstwa i Komunikowania Międzynarodowego, Instytut Dziennikarstwa, Mediów i Komunikacji Społecznej, Uniwersytet Jagielloński; adres do korespondencji: ul. prof. Stanisława Łojasiewicza 4, 30-348 Kraków; e-mail: uhsasins@ @yfronet.krakow.pl; ORCID: https://orcid.org/0000-0002-9628-8496. 
w sobie odporność na nowe przedłużenia, czyli nowe odmiany techniki. Dziś zaczynamy uświadamiać sobie, że sztuka może nam taką odporność zapewnić.

Trudno znaleźć w historii kultury ludzkości przykład świadomego przystosowania różnych aspektów życia osobistego i społecznego do nowych przedłużeń, z wyjątkiem może słabych i zupełnie marginalnych wysiłków podejmowanych w tym kierunku przez artystów. Artysta wyłapuje przesłanie wyzwań kulturowych i technicznych całe dekady wcześniej, zanim dadzą o sobie znać zmiany, do jakich doszło pod wpływem tych wyzwań. Buduje wtedy modele lub arki Noego, żeby się z tymi zmianami zmierzyć (McLuhan, 2004, s. 111).

Powyższe refleksje Marshalla McLuhana, wyrażone przez niego w połowie lat 60. XX w., nabierają dzisiaj - w warunkach otaczającej nas pandemii, która wystąpiła na niespotykaną dotychczas skalę w globalnej wiosce ${ }^{1}-$ no- $^{-}$ wego i zarazem pogłębionego znaczenia. Te przemyślenia dotyczą tego, jakie zmiany zachodzące współcześnie $\mathrm{w}$ społeczeństwie są wywoływane przez coraz bardziej aktywne działania mediów w przestrzeni publicznej i jakie to powoduje ryzyko dla obywateli.

W czym się ono wyraża?

Zjawisko niemal całkowitego zamknięcia społeczeństwa w wyniku pandemii związanej z COVID-19, które rozpoczęło się w Polsce w dniu 14 marca 2020 r. (de facto pierwotnie pandemia ujawniła się jesienią 2019 r. w Chinach, w rejonie miasta Wuhan, w Polsce pierwszy przypadek zakażenia koronawirusem SARS-CoV-2 zanotowano 4 marca 2020 r.), następnie poluzowanie restrykcji, a potem kolejne obostrzenia, które trwają do dzisiaj - wszystko to wywarło znaczący wpływ na życie obywateli niemal w każdej dziedzinie życia. Skutkami pandemii dotknięty został w naszym kraju niemal cały sektor ekonomiczny, polityczny, edukacyjny, kultury, społeczny, w tym szeroko rozumiany wymiar komunikacji międzyludzkiej oraz sfery emocjonalnej. Skutki tego zjawiska zachodzą nie tylko w wymiarze krajowym czy lokalnym, ale - przede wszystkim - w wymiarze globalnym i każdego dnia przynoszą nowe informacje oraz ustalenia w tym zakresie.

Współczesne nam społeczeństwa żyjące na początku trzeciej dekady XXI w. w różnych regionach świata - jak dotąd - nie doświadczyły podobnej sytuacji,

\footnotetext{
${ }^{1}$ Herbert Marshall McLuhan (1911-1980) - kanadyjski teoretyk komunikacji, zawodowo związany z University of Toronto. McLuhan zyskał szeroki rozgłos w latach 60. swoimi pracami i wypowiedziami na temat mediów i komunikacji. Stwierdził, że ludzkość wkracza właśnie w „,wiek informacji”, a elektroniczne media, zwłaszcza telewizja, stworzyły tak zwaną globalną wioskę, w której „medium jest przekazem" (co znaczy, że charakter środka komunikacji ma większy wpływ na odbiorcę niż sama przekazywana wiadomość). Współcześnie powszechnie jest on uznawany w środowisku badaczy komunikowania za jednego z najwybitniejszych teoretyków komunikowania masowego i mediów.
} 
w jakiej obecnie się znaleźli obywatele na całym świecie. Wprawdzie we wcześniejszych okresach XX w. występowały sytuacje wysokiego zagrożenia dla życia obywateli (np. grypa „hiszpanka” w Stanach Zjednoczonych i Europie, AIDS czy wirus ebola na kontynencie afrykańskim), to jednak obecny zakres pandemii nie miał dotąd podobnej skali i charakteru.

Wystąpienie pandemii COVID-19, począwszy od jesieni 2019 r., w skali globalnej spowodowało, że w niezwykle krótkim okresie czasu termin „koronawirus" stał się słowem występującym w przytłaczającej większości ogłaszanych komunikatów publicznych, a także - w następstwie jego rosnącej obecności w przestrzeni zarówno publicznej, jak i prywatnej - w każdej rozmowie. Termin „koronawirus” został uznany za słowo kluczowe roku $2020 \mathrm{w}$ głosowaniu zorganizowanym w 2020 r. Uniwersytecie Warszawskim wśród internautów oraz kapituły językoznawców (Uniwersytet Warszawski, 2020; wyniki plebiscytu ogłoszono 5 stycznia 2021 r.).

Co spowodowało, że komunikacja międzyludzka w związku z wystąpieniem pandemii na skalę globalną uległa tak głębokiej zmianie?

Niemożliwe jest pełne wyjaśnienie mechanizmów tej zmiany, bowiem proces ten w dalszym ciągu toczy się, i to z naszym aktywnym udziałem, a zarazem trudno jest przewidzieć, jaki będzie rezultat docelowy tej zmiany. Niemniej jednak można już poddać wstępnej analizie pierwszą fazę zachodzących zmian w komunikacji międzyludzkiej wywołanej pandemią, która po raz pierwszy odnotowana została w Chinach późną jesienią 2019 r., a do Europy oraz - równolegle - na inne kontynenty wkroczyła w pierwszych miesiącach 2020 r. i trwa do chwili obecnej. I co się wówczas zaczęło, co trwa do dzisiaj, a zarazem powoduje, że trudno jest przewidzieć, kiedy i z jakim skutkiem docelowym zakończy się pandemia? Co aktualnie charakteryzuje życie obywateli w warunkach płynnej pandemii?

Od pierwszych momentów wystąpienia pandemii odnotowano, że z tygodnia na tydzień jednostki były pozbawiane kolejnych aspektów wolności jako obywatele, przy braku jakiejkolwiek, powstałej nawet ad hoc wizji dotyczącej poprawy sytuacji czy powrotu do stanu sprzed wybuchu pandemii. Jedyne, co ujawniło się z całą siłą i pozostaje niezmienne przez cały czas trwania pandemii, to znacząca rola mediów w kształtowaniu percepcji świata, jak i najbliższego otoczenia, kreowania/redukowania poczucia zagrożenia obywateli. I ta wysoka pozycja mediów w czasie dotykającej nas jako obywateli pandemii odnosi się - przede wszystkim - do mediów elektronicznych związanych z Internetem. 


\section{PŁYNNA PANDEMIA - PERSPEKTYWA SOCJOLOGICZNA}

Za prekursora terminu „płynna nowoczesność” (liquid modernity) uznaje się socjologa, Zygmunta Baumana, który zainspirowany wcześniejszymi rozważaniami brytyjskiego socjologa, Anthony Giddensa, na temat późnej nowoczesności (late modernity), wprowadził do nauk społecznych ten termin. Bauman odrzuca pojęcie postnowoczesności, przyjmując, że ona wciąż trwa, a w to miejsce wprowadza powyżej wymienione, nowe pojęcie. Co oznacza w ujęciu Baumana termin „płynna nowoczesność”? - to poczucie niepewności jednostki wobec zmienności bytów, fragmentaryczność, epizodyczność, korozja społecznych dążeń, ideałów i struktur, w obrębie których dotychczas funkcjonowały jednostki. Obecnie - jak zauważa - żyjemy w epoce momentalności (Bauman, 2006, s. 200). Cechy, poprzez które charakteryzujemy zjawisko nowoczesności - jak zauważa Bauman - są współcześnie wysoce niepewne i z tego względu ukazują nieistniejącą już rzeczywistość stabilnych dotychczas struktur społecznych. Świat ,płynnej nowoczesności” to - z jednej strony - kontynuacja, ale - równocześnie - przeciwieństwo stałej nowoczesności, co wymusza w jednostce konieczność dostosowywania się do tego, co zmienia się w przestrzeni publicznej, aby opanować to, co nowe, odmienne i zarazem niezbyt jednoznaczne w odbiorze społecznym (Bauman, 2006, s. 7 n.).

„Płynna pandemia” z kolei oznacza, że obecność koronawirusa SARS-CoV-2 w życiu obywateli wzmocniła osobliwość i zarazem niedookreśloność życia społecznego w warunkach momentalności. Jednostki, żyjąc w warunkach zagrożenia, przede wszystkim biologicznego, które wystąpiło w skali globalnej, nie chcą ponosić odpowiedzialności za skutki działań podejmowanych w sytuacji narastającego zagrożenia, pragnąc zaspokajać swoje potrzeby na dotychczasowych zasadach, co jest trudne do utrzymania. Większość tradycyjnych sposobów radzenia sobie z życiem traci w sytuacji pandemicznej użyteczność i znaczenie. W warunkach pandemii głęboko wchodzimy w świat relacji zapośredniczonych. Jednakże skupiając się na „wirtualnych relacjach”, możemy tracić kontakt z rzeczywistością, z żywymi ludźmi, brakuje nam - ze względu na wymuszoną izolację społeczną - bezpośrednich kontaktów bądź są one bardzo mocno ograniczone. Umieszczenie wiadomości na portalu społecznościowym nie zawiera takiej samej wartości, jak przekazanie jej bezpośrednio drugiej osobie, mając na względzie podstawowe umiejętności komunikowania się między sobą w zbiorowości, w której uczestniczymy. W ten sposób, w sytuacji pandemicznej, jednostki odrywają się od przestrzeni społecznej, w obrębie której dotychczas funkcjonowali. A to nie ułatwia, ale utrudnia nam zapanowanie 
nad zmieniającą się nieustannie rzeczywistością. Wywołuje to - w konsekwencji - poczucie braku realności świata, w którym dotychczas funkcjonowaliśmy. Ten świat zostaje poddany symulacji i zarazem ujawnia swą słabość, bowiem zmienia, a precyzyjniej: ogranicza relacje komunikacyjne obywateli ze światem. Jednostka, broniąc się w sytuacji zaistniałego ryzyka przed stanem samotności, dzięki łatwemu dostępowi do technologii informacyjno-komunikacyjnych wchodzi w niemal permanentne relacje zapośredniczone $\mathrm{z}$ innymi.

Nie ulega wątpliwości, że obecna komunikacja w jej wymiarze globalnym opiera się na Internecie, i to właśnie w tej skali zasięgu oddziaływania można dostrzec kreowanie i analizę występujących tendencji oraz kierunków potencjalnych zmian społecznych, czyli nowych trendów. Różnorodność źródeł wywołujących zmiany sprawia, że jednostka może dokonywać wyboru, na jakim portalu, stronie czy profilu może opierać swoje opinie, bowiem treści komunikatów na nich zamieszczane są dostosowywane do poziomu postrzegania konkretnej grupy docelowej. W związku z tym - w zaistniałej sytuacji pandemicznej - rośnie prawdopodobieństwo manipulacji w obrębie społeczeństw, które doświadczają tej sytuacji. W praktyce może to się przejawiać umiejętnym posługiwaniem się - w warunkach rosnącego zagrożenia pandemicznego - fałszem, m.in. przez przedstawianie niepełnych faktów i obrazów, selekcję informacji ,korzystnych / niekorzystnych”, a także prezentowanie treści o charakterze marketingowym, które wzbudzają zainteresowanie masowego użytkownika mediów (Maciołek, 2014, s. 45-46). Nie bez przyczyny media nazywane były i w dalszym ciągu są określane jako „czwarta władza” (Jastrzębski, 2007), z czasem - przez ich dominującą rolę w społeczeństwie - zaczęto zastępować to określenie mianem ,pierwszej władzy” (Gajda, 2004, s. 42). I ta sytuacja występuje także teraz, gdy pandemia jest obecna już od ponad kilkunastu miesięcy w globalnej wiosce. Media spełniają wiele funkcji, jednakże w tej sytuacji należy się skupić na jednej nich - są naczelnym interpretatorem wydarzeń. Mają na celu przedstawienie swoim odbiorcom bieżących wydarzeń, ich przyczyn, efektów i pośrednio - interpretacji (Milczyńska-Kowalska, Goliszek, 2007, s. 42).

Obecnie, w krótkim czasie od wystąpienia pandemii, społeczeństwa zostały zmuszone do „zwolnienia” swojego tempa i trybu życia, przy równoczesnym ograniczeniu możliwości korzystania z dostępu do kultury i rozrywki. I ta sytuacja trwa do dzisiaj. Na każdym kroku możemy zauważyć, że ruch użytkowników w Internecie znacznie się nasilił, a ludzie, z braku aktywnych form zajęć, które dotychczas realizowali, skupiają swoją uwagę na analizie treści komunikatów medialnych dotyczących pandemii, dostępnych najczęściej 
drogą internetową. Obywatele z niecierpliwością czekają na kolejne oficjalne ogłoszenia przychodzące ze strony władz informujące o tym, w jaki sposób ich życie może się zmienić w następnych dniach oraz jak przedstawiają się dane statystyczne odnoszące się do rosnącej skali zagrożenia. To zjawisko wiąże się pośrednio z równoległym tworzeniem fałszywych informacji, które powstają przez brak klarowności komunikatów, nieadekwatną interpretację czy nadinterpretację komunikatów dokonywaną przez obywateli sfrustrowanego - ze względu na zaistniałą sytuację pandemiczną - społeczeństwa. Wydaje się, że jest to dopiero faza początkowa, prowadząca do znacznie głębszego w skutkach psychologicznego stanu poczucia zagrożenia związanego z komunikacją masową. Społeczeństwo znajdujące się w stanie zagrożenia epidemicznego, przede wszystkim przez brak fachowej wiedzy, dominację tematyki związanej z pandemią, traci dotychczas obecny filtr odnośnie do selekcjonowania informacji prawdziwych na korzyść masowo obecnego szumu informacyjnego. Obywatele wchodzą w stosunkowo krótkim okresie czasu w stan alienacji, są poddawani ciągłej stymulacji, swoistemu bodźcowaniu, które jest wywołane przeżywanym tragizmem dotyczącym występujących zagrożeń. Sytuacja ta występuje w wielu krajach świata, nie tylko w naszym kraju, co prowadzi do tego, że obywatele znajdujący się w stanie zagrożenia przestają „myśleć trzeźwo” i wzajemnie stymulują stan paniki. Tworzy to ogromne wyzwanie dla instytucji medialnych zorientowanych na regularne informowanie obywateli, prowadzi do przedstawiania zaistniałych faktów bez możliwości ich pełnej i wiarygodnej weryfikacji bądź przekazywania błędnych informacji, zwłaszcza gdy zalecenia rządowe nie są w pełni klarowne i sprawdzone. $\mathrm{Z}$ drugiej strony tworzy się podatne podłoże do wszelkiej manipulacji, przez co obywatele - można już wstępnie przewidywać - nie będą w stanie bezpośrednio po przejściu pandemii ponownie zaufać źródłom informacji, z których dotychczas pozyskiwali informacje.

Jedną z szans w komunikacji globalnej w warunkach zagrożenia epidemicznego jest wyjście naprzeciw wszelkim manipulacjom oraz działanie mające na celu umożliwienie edukacji społeczeństwa w wymiarze zrozumiałym dla obywateli oraz opartym na fachowej wiedzy. Internet - jako ogólnodostępne źródło - może stać się narzędziem pozwalającym na zmianę perspektywy spojrzenia na proces zagrożenia oraz ułatwiającym prezentowanie wizji dotyczącej postrzegania świata na dziś i na przyszłość (Castells, 2013). Nawiązać tu można do rozważań hiszpańskiego socjologa i medioznawcy, Manuela Castellsa, wskazujących, że „rozwój masowej komunikacji zindywidualizowanej [...] stwarza nowe perspektywy dla zmiany społecznej w społeczeństwie, które 
we wszystkich dziedzinach życia jest zorganizowane wokół siatki elektronicznych sieci komunikacyjnych" (Castells, 2013, s. 405), mimo że jest to niezwykle trudne do osiągnięcia $w$ obecnych czasach, gdy Internet stał się miejscem wylewania wzajemnych frustracji społeczeństwa. Odnosząc się do analiz Castellsa można przewidywać, że dochodzenie do zmiany społecznej w społeczeństwie sieci wymaga - w tym wypadku społeczeństwa po doświadczeniach zaistniałej pandemii - przeprogramowania sieci komunikacyjnych, stanowiących środowisko symboliczne dla procesów sterowania obrazami dotyczącymi sposobu przetwarzania informacji, które zachodzą w myśleniu jednostki, mającego na celu wypracowanie nowych bądź zmodyfikowanie dotychczas występujących mechanizmów determinujących jednostkowe i zbiorowe praktyki komunikacyjne. Castells postuluje, że

[...] tworzenie nowych treści i form w sieciach łączących proces myślenia [będący pod wpływem przeżytych stanów zagrożenia - T.S.-K.] ze środowiskiem komunikacyjnym jest równoznaczne z przeformatowaniem naszych umysłów. Kiedy zaczynamy czuć i myśleć inaczej, przyswoiwszy nowe znaczenia i nowe reguły interpretacji, wówczas zaczynamy też inaczej działać, a w końcu zmieniamy sposób, w jaki działa społeczeństwo, albo obalając istniejący porządek, albo zawierając nową umowę społeczną, która ustanawia nowe relacje władzy, wynikające ze zmian świadomości zbiorowej. Technologie komunikacji, które wpływają na dane środowisko komunikacyjne, mają więc istotne konsekwencje dla procesów zmiany społecznej. Im większa autonomia komunikujących się jednostek w stosunku do kontrolerów węzłów społecznej komunikacji, tym większe możliwości wprowadzenia do sieci komunikacyjnych komunikatów podważających wpisane w nie wartości i interesy" (Castells, 2013, s. 405).

\section{KOMUNIKACJA W WARUNKACH PŁYNNEJ PANDEMII - ROLA MEDIÓW}

Aktualnie występująca wysoce złożona sytuacja związana z ogólnoświatową pandemią koronawirusa SARS-CoV-2 stanowi nie tylko wyzwanie dla systemów ochrony zdrowia w wymiarze każdego kraju oraz dla rządów tych państw, w których wystąpiły przypadki zakażenia bądź na szeroką skalę rozlała się pandemia koronawirusa. Sytuacja ta stanowi swoisty test/próbę dla oceny efektywności całościowo pojmowanego systemu mediów (zarówno tych o zasięgu globalnym, jak i tych kontynentalnych, krajowych czy lokalnych) odnośnie do jego sprawności informacyjno-edukacyjnej i umiejętności perswazyjnych mających na celu bezpieczne przeprowadzenie informacyjne 
społeczeństw przez falę epidemii. Współczesne media, głównie telewizja, Internet, radio, a także media drukowane są dziś dla przeciętnej jednostki głównym źródłem informacji na temat trudnej sytuacji związanej z pandemią. Stąd - poza instytucjami władzy państwowej - w znaczącym stopniu to właśnie na mediach spoczywa ogromna odpowiedzialność związana z życiem i zdrowiem oraz szeroko pojętym bezpieczeństwem obywateli (Król, 2007).

Media w sytuacji kryzysu, zagrożenia mają za zadanie być aktywne na pierwszej linii frontu $\mathrm{w}$ walce, $\mathrm{w}$ tym przypadku $\mathrm{z}$ wirusem SARS-CoV-2 stojąc równolegle $\mathrm{w}$ jednej linii z personelem medycznym oraz przedstawicielami władzy podejmującymi decyzję w obrębie swoich krajów. Media w takiej sytuacji stają się niejako „pasem transmisyjnym”, łącznikiem między władzą a obywatelami. Ich wiodącym zadaniem - szczególnie istotnym w sytuacji zagrożenia - jest rzetelne informowanie opinii publicznej o zagrożeniach wynikających $\mathrm{z}$ aktualnego etapu rozwoju epidemii, o wszelkich działaniach podejmowanych przez władze kraju, rząd (takie jak wprowadzane obostrzenia, lockdown, nakazy, zakazy, poluzowania itp.), jak i decyzjach podejmowanych przez władze samorządowe (w tym wypadku szczególnego znaczenia nabiera informacyjna rola mediów lokalnych). Chodzi tu o transparentny przekaz informacji na temat liczby nowych zakażeń, sytuacji w placówkach służby zdrowia zaangażowanych $\mathrm{w}$ walkę $\mathrm{z}$ pandemią oraz $\mathrm{w}$ innych instytucjach, które w danym momencie aktywnie włączają się w walkę z koronawirusem ${ }^{2}$. Obok tych wszystkich zadań media w takich kryzysowych sytuacjach mają także obowiązek zadbania o zdrowie i kondycję psychiczną obywateli, którzy w warunkach powszechnie obowiązującej kwarantanny zostają izolowani od „zagrożonego" świata społecznego w swych domach. W tym wypadku media stają się wiodącym, często jedynym kanałem informacji o zagrożeniu i poprzez emisję przygotowanych do tego celu programów edukacyjnych, kulturalnych oraz rozrywkowych łagodzą strach i poczucie zagrożenia. W warunkach zaistniałej od jesieni 2019 r. pandemii wystąpiły też ograniczenia dla obywateli dotyczące ich aktywności w wymiarze religijnym i - co należy odnotować - także w tym zakresie media masowe umożliwiają transmisję

\footnotetext{
${ }^{2}$ Analiza zawartości treści dotyczących sytuacji pandemicznej systematycznie prowadzona w mediach informacyjnych głównego nurtu w naszym kraju wskazuje na to, że w większości przypadków spełniają one oczekiwane wymogi. Chodzi tu o szybkie informowanie o nowych zakażeniach, przekazywanie decyzji podejmowanych przez władzę czy też szeroko pojętą profilaktykę. Niemniej jednak są także odnotowywane błędy komunikacyjne w tym zakresie, np. przekłamania informacyjne, niepełne dane, zabiegi manipulacyjne itp.
} 
wydarzeń o charakterze religijnym, jak i utrzymywanie w formie zapośredniczonej łączności duchowej wiernych $\mathrm{z}$ ich wspólnotami religijnymi ${ }^{3}$.

Według Hansa Roslinga współczesne media częściej informują o skrajnościach aniżeli o zwyczajnych sytuacjach. Sternicy mediów celowo przedstawiają odbiorcom przypadki przesiąknięte przerażającymi faktami. Media bowiem mają za zadanie przyciągnąć uwagę odbiorców, z tego względu używają pewnych zwrotów wspomagających wyobraźnię oglądających lub czytających. Podczas pandemii ujawnia się wyzwanie dla komunikacji związane z tym, czy społeczeństwa nie są za bardzo przesycone informacjami. Trudnością dla przeciętnego odbiorcy mediów może być wywnioskowanie spośród wielu wiadomości, które z nich są prawdziwe, a które pokazują zdeformowany obraz rzeczywistości, tak niełatwej do scharakteryzowania przez dzisiejsze trudne do zrozumienia i opisania wydarzenia (Rosling, 2018, s. 47).

Wspomnianym wcześniej wyzwaniem dla komunikacji międzyludzkiej w warunkach zagrożenia jest obserwowany na szeroką skalę fakt społeczny polegający na tym, że ze względu na wprowadzone przez władze państwowe zaostrzone zasady dotyczące poruszania się obywateli w przestrzeni publicznej ludzie odgradzają się od siebie nawzajem. W konsekwencji ograniczeń oddalają się od siebie, przechodzą - z konieczności - na zapośredniczone formy komunikacji lub słabną między nimi kontakty i więzi społeczne. $Z$ socjologicznego punktu widzenia jest to niekorzystne zjawisko, które - dodatkowo - wywołuje negatywne skutki psychologiczne.

Zgodnie z tym, co opisywał w latach 60 . XX w. McLuhan, rozszerzenie wrażliwości obywateli o media, a także nowe technologie informacyjno-komunikacyjne zmieniło cały system, w którym funkcjonujemy jako obywatele/odbiorcy mediów, a także nasze sposoby zachowania i działania we współczesnej epoce cyfrowej. Zmiany te można porównać do swoistej infekcji, rodzaju choroby, która rozprzestrzenia się w organizmie społeczeństwa. Objawia się ona pogłębiającym się zaburzeniem równowagi między zmysłami i ich „przebodźcowaniem” (McLuhan, 2004, s. 111). W naukach przyrodniczych, jak i w medycynie wyrażany jest pogląd, że mózg człowieka nie potrafi przystosować się do tak szybkiego tempa zmian. Jako obywatele obserwujemy rozprzestrzenianie się najróżniejszych chorób będących następstwem rozwoju cywilizacyjnego,

\footnotetext{
${ }^{3}$ Należy podkreślić, że Polsce w 2020 r. w związku z zaistniałą pandemią do akcji transmisji mszy oraz innych nabożeństw i wydarzeń religijnych włączyły się (oprócz mediów publicznych oraz nadawców społecznych) media komercyjne, mimo iż wcześniej nie realizowały tego w swojej ofercie programowej. Te transmisje są realizowane nie tylko za pośrednictwem telewizji, lecz także w obrębie nowych mediów, takich jak portale internetowe, oficjalne profile na Facebooku, Twitterze, na kanale YouTube $\mathrm{i}$ inne.
} 
wiele z nich ma wyraźne podłoże psychiczne ${ }^{4}$. Ta hipoteza o pogłębiających się skutkach zmian psychicznych pozostających pod wpływem otoczenia, w którym żyjemy, potwierdza się, weryfikuje się z wynikiem pozytywnym. Zauważamy i upewniamy się, że tak się dzieje. Zrealizowane zostały badania, których wyniki wskazują, że media społecznościowe mają związek z niektórymi rodzajami chorób, np. coraz bardziej poszerzającą się zakresowo depresją (Buchalska, 2019). Co się składa na te rezultaty? Można wskazać na jedną spośród wielu przyczyn, polegającą na coraz częstszym byciu „atakowanym” przez nadmiar informacji i bodźców, co w konsekwencji osłabia nasze zdrowie psychiczne i tym samym cały system odpornościowy społeczeństwa. Aktualnie ten stan psychologiczny dotykający całościowo systemu komunikacyjnego społeczeństwa jest spowodowany faktycznie występującą pandemią biologicznego wirusa SARS-CoV-2. Z tego powodu jako obywatele globalnej wioski musimy nie tylko przystosować się do życia w nowym świecie „social distancingu", powstałego z przyczyn sytuacyjnych (pandemia), ale konieczne jest także dla każdego obywatela żyjącego w zasięgu cyfrowego otoczenia opanowanie wiedzy dotyczącej ,informacyjnego zakażenia”, które może mieć równie niebezpieczne skutki, gdy z tej wiedzy nie skorzystamy dla własnej ochrony.

McLuhan pisał już na początku lat 60. XX w. o konieczności zapewnienia sobie odporności na nowe przedłużenia zmysłów, czyli media. Doświadczenia obywateli żyjących w ostatnich dziesięcioleciach odnoszące się do korzystania przez nich z mediów - zwłaszcza nowych mediów, w ujęciu zaproponowanym przez Paula Lewinsona (2009) - pozwalają przypuszczać, że nie wszystko potoczyło się tak, jak prognozowali to autorzy megatrendów. Te prognozy nie w pełni lub w niewielkim stopniu się potwierdziły. Aktywnie współwystępujące we współczesnym nam - jako odbiorcom mediów - środowisku cyfrowym postprawdy, fake newsy, bańki informacyjne, rosnące znaczenie mowy nienawiści (hate speech), nasilające się choroby cywilizacyjne wywołane zostały w ciągu ostatnich kilkunastu lat zmianami w stylu życia, wypracowanym w nowym, ,zdigitalizowanym” otoczeniu. To zmiana, i to bardzo głęboka, która jednoznacznie zaprzecza istnieniu zbiorowej odporności na szum i ferment komunikacyjny, nawet jeśli znaczna część obywateli żyjących $\mathrm{w}$ globalnej wiosce potrafi sobie $\mathrm{z}$ tym poradzić.

\footnotetext{
${ }^{4}$ Według danych zebranych przez WHO liczba zachorowań na takie choroby cywilizacyjne, jak depresja czy schizofrenia nasila się. Zob. opracowanie Kancelarii Senatu (2019), Zdrowie psychiczne w Unii Europejskiej, https://www.senat.gov.pl/gfx/senat/pl/senatopracowania/175/plik/ot-674_zdrowie psychicz ne.pdf [dostęp: 20.10.2020].
} 


\section{KU CZEMU PROWADZĄ ZMIANY \\ W WYMIARZE KOMUNIKACYJNYM?}

Można zadać sobie pytanie: dlaczego komunikacja globalna jest tak ważna w warunkach zagrożenia? Dlatego, że nie tylko wspomaga procesy społeczne, lecz także pozwala na tworzenie różnych scenariuszy działania i kreuje predyspozycje w tym zakresie w wymiarze społecznym, psychologicznym, ekonomicznym, politycznym. To na tej podstawie opierają się dokumenty, umowy międzynarodowe i porozumienia między państwami. I to dzięki nim jesteśmy w stanie tworzyć środowisko interkontynentalne. Także w warunkach niespodziewanego zagrożenia. Media pełnią tu wysoce funkcjonalną rolę.

Zastanowienia wymaga to, czy społeczeństwa potrafią dostosować się do zaistniałej sytuacji zagrożenia? W założeniach logistycznych wprowadzone zasady i ograniczenia, jakie stworzyły rządy krajów dotkniętych pandemią, powinny być skuteczne. W praktyce jednak wygląda to nieco inaczej. W Polsce od 24 marca 2020 r. zaostrzono przepisy obowiązujące od 13 marca w wyniku wprowadzenia stanu zagrożenia epidemiologicznego. I od tej pory do chwili obecnej władze kraju wielokrotnie zaostrzały, ale także liberalizowały wprowadzone ograniczenia. Cel obostrzeń był i w dalszym ciągu jest jasny: chodzi o zdyscyplinowanie, a momentami nawet zastraszenie społeczeństwa, wychodząc z założenia, że zadziała to mocniej i szybciej niż miękka perswazja i pobłażliwość. Jednak tylko do pewnego stopnia osiąga się zamierzony cel.

McLuhan zwracał uwagę, że wprowadzenie w obieg społeczny nowych technologii przypomina przeprowadzenie operacji, ,przeszczepu”, podczas którego przedłużamy swoje zmysły. Zachowanie się systemu społecznego jest uzależnione w dużej mierze od zmysłów. Wyzwania komunikacyjne, jakie zaistniały w warunkach globalnie rozprzestrzeniającej się pandemii wywołanej przez koronawirus SARS-CoV-2, ujawniają liczne słabości dotychczas funkcjonującego systemu społecznego, a zarazem brak odporności ludzkiej na zaistniałe zagrożenie. Dotyczy to zarówno koronawirusa, jak i medialnego przeciążenia, które wystąpiło w warunkach globalnej pandemii. McLuhan w swoich rozważaniach (2004) stawia tezę, iż wszelkie środki służące komunikacji masowej stanowią niejako przedłużenie nas samych. Co więcej, są one istotnym elementem wzmacniającym nasze „być”. To dzięki mediom stajemy się kimś więcej, choć trudno jednoznacznie scharakteryzować, na czym to „wzmacnianie” i „przedłużanie” ma polegać. McLuhan dodaje, że proces rozwoju mediów masowych prowadzący do powstania globalnej wioski stanowi swego rodzaju zbiorową operację na tkance społecznej, i to na poziomie 
ogólnoświatowym. Według niego ten zabieg zbiorowy jest przeprowadzany z niemal całkowitym pominięciem środków bezpieczeństwa, co oznacza, że podczas tej zbiorowej operacji jesteśmy wprost narażeni na zainfekowanie całego organizmu (McLuhan, 2004, s. 111). I tak też się stało w sytuacji pandemii wywołanej przez wirus SARS-CoV-2 w skali globalnej.

Zdaniem McLuhana współczesne społeczeństwa są poddawane niebezpiecznej procedurze quasi-medycznej i przez to narażone na globalną infekcję. Obrazowość tych rozmyślań, w kontekście dzisiejszej sytuacji, jest wyjątkowo mocna i bezpośrednia. Tak jak groźny jest wirus, który wchodząc do organizmu człowieka, pustoszy go od środka, tak samo nieodpowiednie działania w sferze komunikacji masowej mogą pustoszyć tkankę społeczną, doprowadzając do wielu groźnych powikłań, a nawet do samej śmierci organizmu, jakim jest społeczność międzynarodowa.

Jeśli przyjmiemy założenie McLuhana, że żyjemy w globalnej wiosce, to zadaniem mediów powinno być kompleksowe informowanie o kolejnych krokach podejmowanych przez instytucje międzynarodowe i rządy państw w sytuacjach wystąpienia nieoczekiwanej pandemii. Rzetelna komunikacja realizowana na poziomie globalnym, jak i krajowym oraz lokalnym jest obecnie jak najbardziej potrzebna i racjonalna. Każdy odbiorca mediów ma prawo do bezpośredniej informacji od instytucji, które zarządzają kryzysami na poziomie ogólnoświatowym. Media w tym wypadku nie mogą pozostawać obojętne.

Należy zadać sobie pytanie: co może być tym groźnym wirusem atakującym nas jako odbiorców mediów, gdy cały czas jest przeprowadzana ta niekontrolowana do końca zbiorowa operacja? Odpowiedź na to pytanie może dać nawet dość pobieżna analiza przekazów medialnych, które w ostatnim czasie ogniskują się na jednym temacie, jakim jest koronawirus SARS-CoV-2 i - w następstwie - rozwój pandemii na świecie. Globalna tkanka społeczna zagrożona jest - nie ulega to wątpliwości - przez różnego rodzaju niepełne, często wręcz fałszywe wiadomości, informacje, interpretacje, raporty, komentarze, które od jakiegoś czasu określamy w dyskursie publicznym jako fake newsy (Bąkowicz, 2019). Można stwierdzić, że stan ogólnoświatowej epidemii, rzeczywistość, w której każdy myśli o zachowaniu swego zdrowia oraz życia, a przez to nie ma czasu i ochoty na weryfikację wiarygodności komunikatów, jest dogodnym okresem, gdy w mediach „wirus fejków” może się swobodnie, wręcz bez problemu namnażać i rozpowszechniać. Natomiast powszechność tego zjawiska może przynosić miliony „nowych zakażonych” każdego dnia.

W sytuacji rzeczywistego zagrożenia, jakim jest globalna pandemia, skuteczny system komunikacyjny jest niezbędny, aby to zagrożenie zwalczyć. 
W czasach, gdy de facto wszystkie elementy światowego systemu są ze sobą połączone - państwa, przedsiębiorstwa i, przede wszystkim, ludzie tworzący ponadnarodową społeczność światową (Bull, 2002) - niemożliwe jest skuteczne zapobiegnięcie rozprzestrzenieniu się wirusa na wszystkich kontynentach. Niemniej jednak można informować skutecznie o zagrożeniu, a to oznacza bardzo dużo.

$\mathrm{Na}$ koniec należy jeszcze krótko odnieść się do kwestii komunikacji ze strony ogólnoświatowych organizacji, które bezpośrednio zajmują się kwestią pandemii, zwłaszcza do sposobu informowania ze strony Światowej Organizacji Zdrowia (WHO). Ta wyspecjalizowana instytucja ONZ monitoruje na bieżąco stan rozwoju chorób. W przypadku pandemii wywołanej na całym świecie przez wirus SARS-CoV-2 WHO codziennie wysyła podstawowe informacje dotyczące kompleksowych działań, które mają zahamować pandemię koronawirusa. Zadaniem mediów funkcjonujących $\mathrm{w}$ globalnej wiosce powinno być kompleksowe informowanie o kolejnych krokach podejmowanych przez WHO. Rzetelna komunikacja prowadzona na poziomie globalnym jest w obecnym czasie jak najbardziej potrzebna i racjonalna. Każdy odbiorca mediów ma prawo do otrzymywania informacji od instytucji, które zarządzają kryzysem na poziomie ogólnoświatowym, jak np. WHO. Media w tym wypadku nie mogą być obojętne na występujący stan zagrożenia. Powinny być obecne i twórcze w informowaniu i diagnozowaniu zaistniałych zagrożeń.

Przeprowadzona powyżej analiza wskazuje, że świat mediów staje się coraz większy, coraz bardziej skomplikowany i zarazem różnorodny. Ale także coraz trudniej jest go opisać, rozpoznać i zrozumieć. Wszelkie hipotezy i przypuszczenia są obciążone narastającym ryzykiem, a uogólnienia tylko częściowo przystają do dynamicznie zmieniającej się na naszych oczach rzeczywistości, która wymyka się badaczom z całościowego oglądu i jest niełatwa w zakresie konceptualizacji oraz rzetelnej diagnozy.

\section{REFLEKSJE KOŃCOWE: KU CZEMU PROWADZI PŁYNNA PANDEMIA?}

Według McLuhana lekarstwem/antidotum na zmiany wywołane życiem w globalnej wiosce mogą być takie formy działalności, jak aktywność artystyczna czy edukacyjna (2004, s. 111-112). Stanowią one sfery życia człowieka, które sprzyjają wykształceniu się w nas jako jednostkach, a zarazem w systemie odpornościowym społeczeństwa, pewnej otwartości i zarazem elastyczności 
w zakresie działania. Nie ma bowiem nic bardziej destrukcyjnego niż sztywne sądy o świecie i statyczne, oporne na zmiany nastawienie do rzeczywistości. Czy to pomoże w dojściu do normalności społeczeństwom dotkniętym przez koronawirus SARS-CoV-2?

Jak pisze McLuhan, zasoby aktywności ludzkiej sprawdzają się w przystosowaniu jednostki do stałego środowiska. Jednak należy mieć na względzie również to, że nasze otoczenie stale się zmienia - i to coraz szybciej (McLuhan, 2004, s. 112 n.). Zagrożenie, w którym funkcjonuje społeczeństwo, zmienia je w sposób wręcz skokowy. Otwarte na świat myślenie stanowi w tym wypadku pewnego rodzaju szczepionkę. Stałe uczenie się i zaangażowanie w to, co dzieje się w otoczeniu, nacechowanym ryzykiem i zagrożeniem, pozwala lepiej zrozumieć zachodzące przemiany i wypracować odpowiednie nastawienie do zmieniającej się rzeczywistości, ułatwia nam - jako obywatelom, odbiorcom mediów - przezwyciężyć niepewność spowodowaną życiem w warunkach płynnej rzeczywistości, o której pisał brytyjski socjolog, A. Giddens (2001), a także Z. Bauman (2000), a którą obecnie możemy określić jako płynną pandemię, biorąc pod uwagę jej skutki społeczne, psychologiczne i komunikacyjne. Problemem jest to, że nie wszyscy obywatele mają dostęp do tych narzędzi, do nowych technologii informacyjno-komunikacyjnych, które tak głęboko zmieniają nas jako obywateli, a zarazem odbiorców mediów, żyjących w otoczeniu cyfrowym. Powoduje to, że w świecie nowych mediów (new new media) nie słabną, lecz tworzą się nowe podziały społeczne. Procesy globalizacji, jak i postawy antyglobalizacyjne nie powstrzymują tych procesów. Życie w warunkach płynnej pandemii wywołuje głębokie zmiany społeczne i psychiczne wśród obywateli.

To, czego doświadczamy w ostatnich kilkunastu miesiącach w związku z pandemią, skłania do postawienia pytania: czy jest to wirus, który dotknął biednych czy bogatych? Czy zmieni nasze myślenie o rzeczywistości w sposób trwały czy tylko chwilowy? Zastanawiamy się niemal każdego dnia, jakie będzie społeczeństwo polskie po przejściu pandemii? Nikt tego dzisiaj nie wie i to wydaje się w pełni zrozumiałe, że nie jesteśmy w stanie ogarnąć złożoności tego zjawiska. Niemniej powszechnie wypowiadany jest pogląd, że będzie to już inne społeczeństwo, będzie to „inna normalność”, jednakże nie przedstawia się, choćby w najbardziej ogólnych zarysach, jaka może być ta prognozowana/przewidywana - jako wysoce prawdopodobna - ,inna normalność". Z socjologicznej perspektywy można przewidywać, że pandemia, w której zasięgu żyjemy jako obywatele, doprowadzi do większego rozwarstwienia społecznego, zwiększy przyzwolenie społeczne na rządy populistyczne, 
autorytarne, spowoduje wzrost poczucia zagrożenia związanego z doświadczaniem życia w warunkach ryzyka, w świecie ryzyka (risk society), o którym proroczo pisał na przełomie XX i XXI w. niemiecki socjolog, Ulrich Beck (2004). Według badacza narastające ryzyko stanowi uboczny skutek procesu modernizacji. Jest ono samoodnawialne i nieskończone, a także - co je wyróżnia - niezależne od decyzji dokonywanych przez pojedynczych członków społeczeństwa. Tym, co szczególnie wyróżnia ryzyko we współczesnych nam czasach, jest mnożenie się jego odmian i definicji, które często wchodzą ze sobą w konflikt. To przewidywalne - na ten moment - niektóre tylko negatywne skutki społeczne zmian społecznych, a także zmian w komunikacji międzyludzkiej po przeżytej pandemii. Jednak będzie ich znacznie więcej, to jeszcze wszystko przed nami jako obywatelami funkcjonującymi w swoim prywatnym mikroświecie, jak i w globalnym wymiarze. Czas pokaże, jak te przeobrażenia się dokonają, a także jak zmienią nas jako obywateli cyfrowego, globalnego świata.

\section{BIBLIOGRAFIA}

Bauman Z. (2000), Liquid modernity, Cambridge: Polity Press (wyd. pol.: Ptynna nowoczesność, tłum. T. Kunz, Kraków: Wydawnictwo Literackie, 2006).

Bąkowicz K. (2019), Wprowadzenie do definicji i klasyfikacji zjawiska fake newsa, Studia Medioznawcze, t. 20, nr 3(78), s. 280-289.

Beck U. (2004), Społeczeństwo ryzyka. W drodze do innej nowoczesności, tłum. S. Cieśla, Warszawa: Wydawnictwo Naukowe Scholar.

Buchalska K. (2019), Facebook niszczy twoje zdrowie psychiczne, https://forsal.pl/artykuly/1432479, facebook-niszczy-twoje-zdrowie-psychiczne-infografika.html [dostęp: 3.10.2020].

Bull H. (2002), The anarchical society. A study of order in world politics, New York, Columbia: University Press.

Castells M. (2013), Władza komunikacji, tłum. J. Jedliński, P. Tomanek, Warszawa: Wydawnictwo Naukowe PWN.

Gajda J. (2004), Media w edukacji, Kraków: Oficyna Wydawnicza „Impuls”.

Giddens A. (2001), Nowoczesność i tożsamość. „Ja” i spoteczeństwo w epoce późnej nowoczesności, tłum. A. Szulżycka, Warszawa: Wydawnictwo Naukowe PWN.

Jastrzębski J. (2007), Misja, „czwarta władza” czy biznes? O potrójnej naturze mediów, [w:] M. Szpunar (red.), Media a polityka, Rzeszów: WSIiZ, s. 153-165.

Kancelaria Senatu (2019), Zdrowie psychiczne w Unii Europejskiej, https:// www.senat.gov.pl/gfx/se nat/pl/senatopracowania/175/plik/ot-674_zdrowie_psychiczne.pdf [dostęp: 20.10.2020].

Król J. (2007), Człowiek w świecie mediów. Tożsamość jako towar, [w:] B. Siemieniecki, Manipulacja. Media. Edukacja, Toruń: Wydawnictwo Adam Marszałek, s. 59-60.

Lewinson P. (2009), New New Media, Boston, MA: Allyn \& Bacon. 
Maciołek D., Poleszak D. (2014), Wptyw manipulacji medialnej na kształtowanie się tożsamości wspótczesnej młodzieży, Kultura - Media - Teologia, nr 19(4), s. 45-59.

McLuhan M. (2004), Zrozumieć media. Przedtużenia człowieka, tłum. N. Szczucka, Warszawa: Wydawnictwa Naukowo-Techniczne.

Milczyńska-Kowalska M., Goliszek A. (2007), Media jako czwarta władza, [w:] M. Szpunar (red.), Media - między wtadzq a spoteczeństwem, Rzeszów: WSIiZ 2007, s. 39-50.

Rosling H. (2018), Factfulness. Dlaczego świat jest lepszy, niż myślimy, czyli jak stereotypy zastapić realna wiedza, tłum. M. Popławska, Poznań: Media Rodzina.

Siemieniecki B. (2007), Manipulacja. Media. Edukacja, Torun: Wydawnictwo Adam Marszałek.

Uniwersytet Warszawski (2020), Wyniki plebiscytu Słowo Roku 2020, https://www.uw.edu.pl/wy niki-plebiscytu-slowo-roku-2020/ [dostęp: 5.01.2021].

\section{WYZWANIA KOMUNIKACYJNE W CZASACH PŁYNNEJ PANDEMII - PERSPEKTYWA SOCJOLOGICZNA}

Streszczenie

Co spowodowało, że komunikacja międzyludzka w związku z pojawieniem się pandemii na skalę globalną, począwszy od jesieni 2019 r., uległa tak głębokiej zmianie? Ujawniła się wówczas z całą siłą - i pozostaje niezmiennie przez cały czas trwania pandemii - znacząca rola mediów w kształtowaniu percepcji świata, jak i najbliższego otoczenia, kreowania / redukowania poczucia zagrożenia obywateli. Wysoka pozycja mediów w czasie dotykającej nas jako obywateli pandemii odnosi się - przede wszystkim - do mediów elektronicznych związanych z Internetem. Sytuacja ta stanowi swoisty test / próbę dla oceny efektywności całościowo pojmowanego systemu mediów (zarówno tych o zasięgu globalnym, jak i tych kontynentalnych, krajowych czy lokalnych) odnośnie do jego sprawności informacyjno-edukacyjnej i umiejętności perswazyjnych mających na celu bezpieczne przeprowadzenie informacyjne społeczeństw przez falę epidemii.

Słowa kluczowe: pandemia; komunikacja; globalizacja; społeczeństwo ryzyka; SARS-CoV-2.

\section{COMMUNICATION CHALLENGES IN TIMES OF A LIQUID PANDEMIC - A SOCIOLOGICAL PERSPECTIVE}

\section{Summary}

What caused interpersonal communication in connection with the appearance of the pandemic on the global website, in the fall of 2019. has changed so profoundly? It then revealed itself in full force and remains unchanged throughout the duration of the pandemic, the significant role of the media in shaping the perception of the world and the immediate environment, creating / reducing the sense of threat to citizens.And this high position of the media during the pandemic affecting us as citizens concerns ul. Prof. S. Łojasiewicza 4-above all-electronic media related to the Internet. This situation is a specific test / trial to assess the effectiveness of the overall media system (both global and continental, national or local) in terms of its informational and educational efficiency and persuasive skills aimed at safe informing societies through the epidemic wave.

Keywords: pandemic; communication; globalization; risk society; SARS-CoV-2. 